\title{
Прояв спеціальної працездатності жінок-боксерів високого класу
}

\author{
УдК 796.83+612.766.1:796 \\ О. М. Лисенко ${ }^{1,3}$, С. Ф. Гасанова², О. А. Шинкарук, \\ С. В. Федорчук ${ }^{3}$, О. В. Колосова ${ }^{3}$
}

${ }^{1}$ Київський університет імені Бориса Грінченка, Київ, Україна

${ }^{2}$ Київський національний університет будівництва та архітектури, Київ, Україна

${ }^{3}$ Національний університет фізичного виховання і спорту України, Київ, Україна

Резюме. Останнім часом у жіночому боксі зростає напруження змагальної боротьби. Тому в системі підготовки жінок-боксерів все більше уваги приділяється вдосконаленню тих компонентів підготовленості, які дозволяють забезпечити високий рівень працездатності в умовах підвищеного напруження функціонального забезпечення змагальної діяльності. Мета. Визначити особливості прояву спеціальної працездатності і її функціонального забезпечення у жінок-боксерів високого класу залежно від рівня їх тренованості. Методи. Хронодинамометрія «Спудерг-10», спірометрія і газоаналіз («Meta Max 3В» («Cortex», Німеччина)), математична статистика. Результати. Жінки-боксери високого класу мають відмінності за рівнем та особливостями прояву спеціальної працездатності залежно від того, чи були вони лідерами, чи аутсайдерами у команді в період проведення дослідження. Жінки-боксери, що є лідерами у команді, демонструють більш високий рівень анаеробних можливостей організму. Так, при проведенні тесту «40 c», що вимагає максимальної мобілізації анаеробних гліколітичних можливостей, майже однаковий сумарний «тоннаж» нанесених ударів за тест досягається різними шляхами. Більш високий ступінь позитивного взаємозв'язку кількості нанесених ударів з рівнем виділення $\mathrm{CO}_{2}(r=0,530 ; p<0,05)$, ніж з рівнем споживання $\mathrm{O}_{2}(r=0,263 ; p>0,05)$, що свідчить про більше значення дихальної компенсації зростаючого ступеня ацидозу для досягнення високого рівня спеціальної працездатності жінок-боксерів вже при короткочасному анаеробному навантаженні максимальної інтенсивності. Визначено, що більша кількість нанесених ударів за меншої їх сили відзначається у жінок-боксерів високого класу - лідерів команди, що є більш раціональною моделлю прояву спеціальної працездатності з огляду на те, що у жінок-боксерів високого класу, які здобули перемогу на чемпіонатах світу, Іграх Олімпіад, відзначається достовірно більша кількість нанесених ударів, ніж у їх суперниць. Для формування високого темпу нанесення ударів, навіть при короткочасній роботі анаеробного характеру, найбільш сприятливим є економний тип дихальної реакції, коли високий рівень легеневої вентиляції формується за рахунок збільшення дихального об'єму.

Ключові слова: жінки-боксери, функціональні можливості, спеціальна працездатність, кардіореспіраторна система.

Manifestation of special work capacity of high-class female-boxers

O. M. Lysenko 1,3, S. F. Gasanova ${ }^{2}$, O. A. Shynkaruk ${ }^{3}$, S. V. Fedorchuk ${ }^{3}$, O. V. Kolosova ${ }^{3}$

${ }^{1}$ Kyiv Boris Grinchenko University, Kyiv, Ukraine

${ }^{2}$ Kyiv National University of Construction and Architecture, Kyiv, Ukraine

${ }^{3}$ National University of Physical Education and Sport of Ukraine, Kyiv, Ukraine

Abstract. Recently, the intensity of competitive fighting in women's boxing is growing. Therefore, in the system of training female-boxers a much greater attention is paid to the improvement of those fitness components that allow to ensure a high level of efficiency in conditions of increased functional stress of the the competitive activity. Objective. To determine the features of special work capacity manifestation and its functional support in female boxers of high class depending on the level of their training status. 
Methods. Method of chrono-dynamometry «Spuderg-10», spirometers and gas analysis («Meta Max 3B» («Cortex», Germany)), methods of mathematical statistics.

Results. Highly skilled female-boxers differ in the level and peculiarities of special work capacity manifestation depending on whether they are leaders or outsiders in the team during the study period. Leaders demonstrate a higher level of anaerobic capacity of the body. When performing the test «40 s», which requires maximum mobilization of anaerobic glycolytic capacity, there was almost the same total tonnage of the applied strikes. A higher degree of positive relationship of the number of blows with the level of $\mathrm{CO}_{2}(r=0.530, p<0.05)$ than that of $\mathrm{O}_{2}$ consumption $(r=0.263, p>$

$>0.05$ ) indicates a greater value of respiratory compensation of the increasing degree of acidosis for achievement of the high level of special work capacity under short-term anaerobic load of maximum intensity. More blows, with less force, were inflicted by the leaders, which is a more rational model of special work capacity manifestation. For the formation of a high blow rate, even with short-term anaerobic work, the most favorable is the economical type of respiratory response, when a high level of pulmonary ventilation is formed by increasing the tidal volume.

Keywords: female-boxers, functional possibilities, special endurance, cardiorespiratory system.

Постановка проблеми. 32012 р. жіночий бокс включено в програму Ігор Олімпіад, систематично проводяться чемпіонати світу, престижні міжнародні змагання, значно зросла $[1,4]$ конкуренція i, як наслідок, зростає напруженість змагальної боротьби. Тому в системі підготовки жінок-боксерів все більше уваги приділяється не лише вдосконаленню їх спеціальних умінь та навичок, а й тих компонентів підготовленості, що дозволяють забезпечувати високий рівень працездатності в умовах підвищеного напруження функціонального забезпечення змагальної діяльності $[3,5,11,15,17]$, у т. ч. прогресуючого стомлення організму спортсменок [12, $15,20,21]$. Особливого значення набуває рівень анаеробних i, зокрема, гліколітичних можливостей організму спортсменок для демонстрації високого рівня їх спеціальної працездатності $[2,6,8,11,13,16]$.

Необхідно зазначити відсутність у науковій та науково-методичній літературі даних про фуннкціональне забезпечення спеціальної працездатності спортсменок в умовах виконання навантажень анаеробного характеру, що істотно обмежує можливості визначення спеціалізованої спрямованості фрізичної підготовки, уточнення режимів роботи та управління на цій основі спеціальною фрізичною підготовленістю жінок-боксерів [3, 5, $11,14,16]$. У боксі для ведення результативного поєдинку необхідно володіти високим рівнем розвитку вибухової сили, яка потрібна для нанесення нокаутуючого удару. "Швидкісна» витривалість боксера полягає в його здатності багаторазово проявляти швидкі м'язові зусилля (без зміни організаційної структури руху), а також в умінні провести весь поєдинок у високому темпі. «Силова» витривалість проявляється у здатності спортсмена тривалий час докладати максимальних швидкісно-силових зусиль, не знижуючи потужності м'язової роботи до завершення поєдинку. «Швидкісна» $\mathrm{i}$ «силова» витривалість $\epsilon$ важливими компонентами структури фрізичної підготовки боксера $[3,6,10,11,16,17]$. Усе це визначає необхідність враховувати специярічні вимоги до функціонального забезпечення спеціальної працездатності жінок-боксерів високого класу, а також особливостей реалізації ними анаеробних і аеробних можливостей організму $[2,4,6$, 16, 17]

Мета дослідження - визначити особливості прояву спеціальної працездатності і її функціонального забезпечення у жінок-боксерів високого класу залежно від рівня їх тренованості.

Методи дослідження: хронодинамометрія «Спудерг-10», спірометрія і газоаналіз («Meta Max 3B» («Cortex», Німеччина)), математична статистика.

Результати дослідження та їх обговорення. Дослідження проводили з дотриманням біоетичних вимог за участю 21 спортсменки від 19 до 24 років, що мали кваліфікацію ЗМС, МСМК, МС. Для стандартизації умов тестування й отриманих результатів у дослідженні брали участь жінки-боксери вагових категорій: перша напівсередня; напівсередня; середня. Згідно з даними календарних диспансерних обстежень, усі спортсменки були практично здорові.

У природних умовах тренувального заняття для визначення спеціальної працездатності боксерів застосовували метод хронодинамометрії «Спудерг-10» конструкції М. П. Савчіна [7, 10, $18,19]$, який дозволяв реєструвати кількість ударів (К, к-ть); силу кожного удару $\left(\mathrm{F}_{\mathrm{yg}}\right.$, у.о.), загальний «тоннаж» ударів, часовий інтервал між ударами ( $\left.\mathrm{T}_{\text {уд }}, \mathrm{MC}\right)$ i час реакції спортсменок на сигнал ( $\mathrm{T}, \mathrm{Mc})$. Для визначення спеціальної анаеробної працездатності використовували тести «8 c» i «40 c» $[6,19]$ з подальшим розрахунком показників - сумарний «тоннаж» ударів (F8, $\mathrm{F} 40$, у.о.), коефріцієнт «вибухової» витривалості (КВВ, у.о.), індекс «вибухової» витривалос- 
ті (IBB, у.о.), індекс креатинфоссфатної працездатності (ІКФП, у.о.), коефріцієнт «швидкісної» витривалості (КШВ, у.о.), індекс «швидкісної» витривалості (ІШВ, у.о.), індекс гліколітичної працездатності (ІГЛП, у.о.), інтегральний індекс потужності роботи (IIПР, у.о.), інтегральний індекс швидкісно-силової підготовленості (ІІШСП, у.о.).

Безперервне комп'ютерне опрацювання даних у реальному масштабі часу «breath-bybreath» [21] проводили за допомогою ергоспірометричного комплексу «Meta Max 3B» («Cortex», Німеччина), що дозволило оцінити реакцію кардіореспіраторної системи на тестові навантаження. Визначали легеневу вентиляцію $\left(\mathrm{V}_{\mathrm{E}}\right)$, частоту дихання $\left(\mathrm{F}_{T}\right)$, дихальний об'єм $\left(\mathrm{V}_{\mathrm{T}}\right)$, споживання $\mathrm{O}_{2}\left(\mathrm{VO}_{2}\right)$ і виділення $\mathrm{CO}_{2}\left(\mathrm{VCO}_{2}\right)$, газообмінне відношення $\left(\mathrm{VCO}_{2} \cdot \mathrm{VO}_{2}^{-1}\right)$, вентиляційні еквіваленти для $\mathrm{O}_{2}\left(\mathrm{EQO}_{2}\right)$ і для $\mathrm{CO}_{2}\left(\mathrm{EQCO}_{2}\right)$, кисневий пульс («О -пульс»). Враховуючи, що вимірювання проводили у відкритій системі, показники зовнішнього дихання були приведені до умов BTPS, а газообміну - до умов STPD. Вимір частоти серцевих скорочень (ЧСС) проводили за допомогою «Sport Tester Polar-810і» (Фінляндія). Вміст лактату (HLa) в капілярній крові визначали ензиматичним методом (стандартний набір реактивів LKM 140, «Dr. Lange-400», Hiмеччина). Калібрування всіх приладів проводили до і після обстеження кожного спортсмена. Діагностичне обладнання відповідає міжнародним стандартам контролю якості та безпечності (ISO9001, ISO-13485).

Статистичну обробку експериментального матеріалу здійснювали на персональному комп'ютері IBM PC «Pentium» за допомогою пакета стандартних комп'ютерних програм математичної статистики «Microsoft Excel», «STATISTICA-6». Обробку отриманих даних виконували з урахуванням рекомендацій спеціальної літератури 3 математичної статистики і досвіду раніше проведених досліджень [9].

За результатами змагальної діяльності сформовано дві групи спортсменок. У групі лідерів команди були спортсменки високого класу, які в період досліджень виборювали на національних та міжнародних змаганнях перші місця, а у групі аутсайдерів - спортсменки, що в період досліджень отримали на змаганнях посередні спортивні результати. Такий поділ жінок-боксерів на групи дозволив визначити особливості прояву спеціальної працездатності при виконанні тестів в анаеробних умовах енергозабезпечення, а також особливості функціонального забезпечення спеціальної працездатності, що сприяють досягненню високих спортивних результатів.

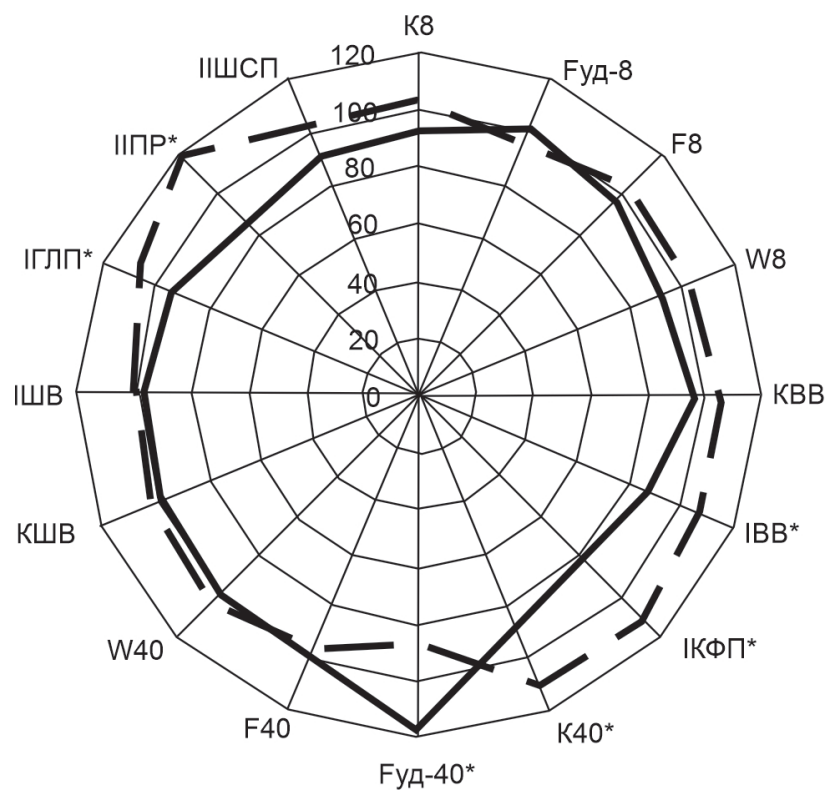

Рисунок 1 - Характеристики спеціальної працездатності жінок-боксерів високого класу під час проведення тестів анаеробного характеру (відносно середніх значень по команді, прийнятих за $100 \%$ ):

- II група - жінки-боксери - аутсайдери команди; - - - I група - жінки-боксери - лідери команди;

* достовірні відмінності між групами $(p<0,05)$

У результаті дослідження виявлено відмінності спеціальної працездатності у жінок-боксерів високого класу, які є лідерами чи аутсайдерами у команді. Так, на рисунку 1 представлено відмінності груп жінок-боксерів щодо показників їх спеціальної працездатності при виконанні тестів «8 с» $\mathrm{i}$ «40 с» в анаеробних умовах енергозабезпечення тестового навантаження $[6,10,18$, 19]. Відмінності зазначених груп виражено у відсотках відносно середніх значень у команді, що прийняті за $100 \%$. Ці особливості відображають зміни, що забезпечують ефективність і результативність ЗД спортсменок високого класу.

Як видно з даних, представлених на рисунку 1 , у жінок-боксерів - аутсайдерів відзначається найменший рівень спеціальної працездатності порівняно з лідерами, що відповідно становить 79,48-102,13 \% за різними показниками відносно середніх даних по команді, прийнятих за $100 \%$. У групі жінок-боксерів високого класу, що $є$ лідерами, різні показники спеціальної працездатності становлять 95,55-117,79 \% відносно середніх даних щодо всіх спортсменок команди.

Як видно з даних, представлених в таблиці 1, між жінками-боксерами, які були лідерами чи аутсайдерами у команді, не виявлено значних відмінностей за кількістю нанесених ударів у короткочасному тесті «8 c» 3 анаеробним креатинфоосфатним енергозабезпеченням $(p>0,05)$. Лі- 
ТАБЛИЦЯ 1 - Характеристики спеціальної працездатності при виконанні тесту «8 с» у жінок-боксерів високого класу, що були лідерами чи аутсайдерами у команді на період обстеження, $n=21, \bar{x} \pm \mathbf{S}$

\begin{tabular}{|c|c|c|c|}
\hline \multirow[b]{2}{*}{ Показники } & \multirow{2}{*}{$\begin{array}{c}\text { Середні } \\
\text { значення по } \\
\text { команді, } n=21\end{array}$} & \multicolumn{2}{|c|}{ Групи спортсменок } \\
\hline & & $\begin{array}{l}\text { аутсайдери, } \\
n=5\end{array}$ & лідери, n = 5 \\
\hline Кількість ударів, К8, к-сть разів & $42,60 \pm 1,70$ & $39,40 \pm 2,43$ & $43,80 \pm 4,14$ \\
\hline Сумарний «тоннаж» ударів, F8, у.о. & $816,47 \pm 51,35$ & $786,20 \pm 53,63$ & $839,40 \pm 84,03$ \\
\hline Сила одиночного удару, F, у.о. & $19,87 \pm 0,16$ & $19,95 \pm 0,14$ & $19,16 \pm 0,18$ \\
\hline $\begin{array}{l}\text { Коефріцієнт «вибухової» } \\
\text { витривалості, КВВ, у.о. }\end{array}$ & $0,92 \pm 0,03$ & $0,88 \pm 0,04$ & $0,97 \pm 0,05^{\star}$ \\
\hline $\begin{array}{l}\text { Індекс «вибухової» витривалості, } \\
\text { ІВВ, у.о. }\end{array}$ & $1,55 \pm 0,10$ & $1,35 \pm 0,13$ & $1,64 \pm 0,12^{*}$ \\
\hline $\begin{array}{l}\text { Індекс креатинфоссфатної } \\
\text { працездатності, ІКФП, у.о. }\end{array}$ & $66,43 \pm 5,61$ & $52,82 \pm 4,75$ & $73,41 \pm 3,52^{*}$ \\
\hline
\end{tabular}

* відмінності достовірні між групами аутсайдерів і лідерів у команді, $p<0,05$

3 меншою силою нанесення ударів $\mathrm{F}_{\text {ул }} 4011,72 \pm 1,03$ у.о. $(\mathrm{p}>0,05)$, що становить відносно середніх даних по команді 95,55 $\pm 2,01 \%$ (див. рис. 1). У жінок-боксерів аутсайдерів у команді відзначається протилежна закономірність: достовірно менша кількість нанесених ударів за 40 с тесту К40 $148,20 \pm 7,04$ к-сть разів $(87,57 \pm$ $\pm 3,25 \%, p<0,05)$ поєднується 3 більшою силою нанесення ударів F $4015,56 \pm 1,01$ y.o. $(102,13 \pm$ $\left.\pm^{\mathrm{yA}} 2,84 \% ; p<0,05\right)$.

Таким чином, у лідерів відзначається достовірно більша кількість нанесених ударів за 40 с тес-

дерів у команді відзначає дещо більша кількість ударів при меншій їх силі (р>0,05), що і фрормує у них більший сумарний «тоннаж» ударів F8 839,40 \pm 84,03 у.о, що становить 102,82 \% від середніх даних по команді. В аутсайдерів загальна кількість ударів найменша і становить 92,49 \pm 3,87 \% від середніх даних. При цьому в аутсайдерів відзначається найбільша сила одиночного удару, але сумарний їх «тоннаж» за 8 с тесту F8 786,20 \pm 53,63 у.о. найменший i становить 96,29 $\pm 2,14 \%$ від середніх даних по команді.

Розрахований КВВ, що характеризує співвідношення сили ударів до їх кількості на початку та в кінці тесту, в групі спортсменок-аутсайдерів становив 0,88 \pm 0,04 у.о., що свідчило про більший темп нанесення ударів на початку тесту, ніж у кінці - темп не утримують. Жінки-боксери - лідери у команді у тесті «8 с» розвивають меншу силу ударів при більшому темпі їх нанесення, який вони утримують усі 8 с, і це поєднується з найбільшим IBB й індексом анаеробної креатиноросфратної працездатності. Це підтверджує і достовірно більший у них КВВ 0,97 \pm 0,05 у.о. (105,43 $\pm 2,84 \%$ відносно середніх даних по команді $р<0,05)$, IBB 1,64 \pm 0,12 у.о. (105,81 $\pm 3,02 \%)$, а також ІКФП 73,41 \pm 3,52 (110,51 \pm 3,45 \%, p < 0,05).

Подібні закономірності, але більш виражені відзначаються між спортсменками - лідерами чи аутсайдерами у команді при визначенні їх спеціальної працездатності у тесті «40 с», що сприяє реалізації анаеробних гліколітичних можливостей жінок-боксерів (табл. 2). Так, у жінок-боксерів - лідерів у команді відзначається достовірно більша кількість нанесених ударів за 40 с тесту: $187,80 \pm 6,37$ к-сть разів ( $<<0,05)$, що становить $110,97 \pm 2,58 \%$ від середніх даних по команді $(p<0,05)$. У спортсменок-лідерів це поєднується ту при достовірно меншій силі одиночного удару порівняно $з$ аутсайдерами команди. При цьому не виявлено достовірних відмінностей серед жінок-боксерів за величиною сумарного «тоннажу» ударів за 40 с тесту ( $>$ 0,05), що свідчить про те, що один і той самий сумарний «тоннаж» ударів досягається у тесті «40 с» за рахунок різного співвідношення кількості нанесених ударів i їх сили. Як видно з аналізу даних, представлених у таблиці 2 і на рисунку 1 , у жінок-боксерів - аутсайдерів більший «тоннаж» ударів F40 $2304,40 \pm 183,95$ у.о. ( $>>0,05)$ досягається за рахунок більшої сили, що розвивається при нанесенні ударів ( $<<0,05)$. У жінок-боксерів - лідерів у команді, навпаки, дещо менший «тоннаж» F40 2156,01 $\pm 130,79$ у.о. досягається за рахунок більшої кількості нанесених ударів протягом тесту «40 с» (p < 0,05). Саме достовірно більша кількість нанесених ударів у спортсменок - лідерів у команді дозволяє їм демонструвати більш високий розрахунковий ІГЛП порівняно зі спортсменками-аутсайдерами: ІГЛП 60,05 \pm 2,42 у.о., що становить 107,81 \pm 4,01 \% від середнього значення даних по команді ( $<<0,05)$. Очевидно, що більша кількість нанесених ударів при меншій їх силі Відзначається у жінок-боксерів Високого класу лідерів команди, що є більш раціональною моделлю прояву спеціальної працездатності з огляду на те, що у жінок-боксерів Високого класу, які здобули перемогу у поєдинку на чемпіонатах свіmy, Іграх Олімпіад, Відзначається достовірно більша кількість нанесених ударів, ніж у їхніх суперниць.

Більший рівень анаеробних можливостей спортсменок, що $є$ лідерами збірної команди України з боксу, дозволяє їм демонструвати високу результативність змагальної діяльності. Це підтверджує достовірно вищий ІІПР, що об'єднує 
IBB й ІШВ і відзначається у групі жінок-боксерів - лідерів у команді (ІІПР 2,35 \pm 0,06 у.о.) порівняно 3 аутсайдерами (IIПР $2,07 \pm 0,07$ у.о.). ІІШСП об'єднує досягнутий рівень анаеробних креатинфосоратних можливостей боксерів за ІКФП і рівень їх анаеробних гліколітичних можливостей за ІГЛП, також достовірно більш високий рівень ІІШСП у жінок-боксерів - лідерів (ІІШСП 143,86 \pm 9,64 у.о.; $p<$ $<0,05)$, ніж в аутсайдерів (ІІШСП $105,37 \pm 9,46$ у.о.; $p<0,05)$.

Таким чином, у досягненні високого рівня спеціальної швидкісної витривалості жінками-боксерами має значення інтенсивний темп нанесення ударів при меншій їх силі, чому сприяє більший рівень активності анаеробних гліколітичних процесів у енергозабезпеченні в поєднанні 3 дихальною компенсацією наростаючого ступеня ацидозу (за $\mathrm{VCO}_{2}$, $\left.\mathrm{VCO}_{2} / \mathrm{VO}_{2}\right)$. Високому рівню спеціальної працездатності сприяє також і більший рівень реалізації аеробного потенціалу при більшій ефективності діяльності серцево-судинної системи. Так, жінки-боксери - лідери у команді при виконанні тесту «40 с» демонструють найбільший у команді рівень легеневої вентиляції та пік споживання $\mathrm{O}_{2}$, що становить 75,86 $\pm 4,19 \%(p<0,05)$ реалізації аеробного потенціалу спортсменок за цих умов. Жінки-боксери - аутсайдери у команді за умов тесту «40 с» досягають достовірно меншого рівня $\mathrm{V}_{\mathrm{E}}$ i VO $(\mathrm{p}<0,05)$ при меншому рівні реалізації аеробного потенціалу організму (РАП $69,75 \pm 4,98 \%, p>0,05)$. При цьому лідерів у команді характеризує і більша економічність діяльності серцево-судинної системи за даних умов тесту: менший рівень ЧСС поєднується з більшим $\mathrm{O}_{2}$-пульсом. Відзначимо, що більший «тоннаж» ударів за 40 с субмаксимального тесту поєднується у відновлювальному періоді з більш високим рівнем легеневої вентиляції $\left(V_{\mathrm{E}} r=0,590\right.$, $\mathrm{p}<0,05)$ при більш високому дихальному об'ємі $\left(\mathrm{V}_{\mathrm{T}} \mathrm{r}=0,639, \mathrm{p}<0,05\right)$ та ефективністю дихальної реакції $\left(\mathrm{VO}_{2} \cdot \mathrm{F}_{\mathrm{T}}{ }^{-1} \mathrm{r}=0,587, \mathrm{p}<0,05\right)$, що характеризує більш економний тип дихальної реакції. При цьому відзначається більш високий рівень споживання $\mathrm{O}_{2}\left(\mathrm{VO}_{2} r=0,687, \mathrm{p}<0,05\right)$ i виділення $\mathrm{CO}_{2}\left(\mathrm{VCO}_{2} r=0,773, \mathrm{p}<0,05\right)$.

Аеробні можливості організму жінок-боксерів впливають на прояви спеціальної працездатності за умов виконання спеціалізованих тестів «8 с» $\mathrm{i}$ «40 с», які вимагають максимальної ак- тивізації анаеробних процесів в їх енергозабезпеченні, що підтверджує отримані дещо раніше дані О. М. Лисенко та Д. Ю. Берінчика [14]. Так, виявлено позитивний кореляційний зв'язок між кількістю нанесених ударів у тесті «8 с» та показниками, що характеризують реакцію кисневотранспортної системи $\left(\mathrm{V}_{\mathrm{E}} \mathrm{r}=0,621, \mathrm{~V}_{\mathrm{T}} \mathrm{r}=0,547\right.$, $\left.\mathrm{VCO}_{2} r=0,530, \mathrm{VCO}_{2} \cdot \mathrm{VO}_{2}^{-1} r=0,584, p<0,05\right)$ за весь період тесту, включаючи 8 с нанесення ударів у максимальному темпі і 22 с відновлювального періоду, тобто за загальний час тесту 30 с. Таким чином, високий темп нанесення ударів навіть при короткочасній роботі анаеробного креатинфоссратного характеру відзначається у спортсменок-лідерів, які відрізняються від інших більш економним типом дихальної реакції, коли вищий рівень легеневої вентиляції формується за рахунок більшого дихального об'єму, і при виконанні тестового навантаження, і у відновлювальному періоді. При цьому відзначається більш високий ступінь позитивного взаємозв'язку кількості нанесених ударів з рівнем виділення $\mathrm{CO}_{2}(r=0,530, p<0,05)$, ніж з рівнем споживання $\mathrm{O}_{2}(r=0,263, p>0,05)$, що свідчить про більше значення дихальної компенсації наростаючого ступеня ацидозу вже при виконанні короткочасного високоінтенсивного фрізичного навантаження анаеробного характеру для досягнення високого рівня спеціальної працездатності.

Необхідно відзначити, що правила проведення змагань у жіночому боксі передбачають відпочинок спортсменок - три однохвилинні перерви між раундами за час бою $[1,3,11]$. Цей час організм спортсменки використовує для ліквідації нестачі кисню, продуктів розпаду (субстрати молочної кислоти та ін.), що утворилися в результаті роботи і в подальшому ускладнюють скорочувальну здатність м'язів. Іншими словами, організм спортсменки хоч і неповною мірою, 
але відновлює свій запас енергетичних ресурсів і ліквідує продукти розпаду. Результатом цього $\epsilon$ відновлення працездатності організму, яке залежить від рівня аеробних реакцій $[16,18]$. Очевидно, чим вище у спортсменок рівень споживання $\mathrm{O}_{2}$ під час фрізичної роботи та у період відновлення (перерви між раундами тощо), тим менше рівень нестачі кисню і тим швидше він ліквідується [14, 16].

\section{Висновки}

1. Жінки-боксери високого класу, які $\epsilon$ лідерами у команді, демонструють вищий рівень швидкісно-силової працездатності, що зумовлений анаеробними можливостями організму спортсменок. Достовірно більший коефіцієнт «вибухової» витривалості у жінок-боксерів лідерів свідчить про утримання ними високого темпу ударних дій при виконанні короткочасного тесту максимальної інтенсивності. В аутсайдерів порівняно невеликий темп ударних комбінацій, який вони розвивають на початку тесту «8 с», спортсменки не утримують його до завершення тесту.

2. Більша кількість нанесених ударів при меншій їх силі, що відзначається у жінок-боксерів лідерів у команді, є більш сприятливою моделлю прояву спеціальної працездатності в жіночому боксі. Майже однаковий сумарний «тоннаж» нанесених ударів при навантаженні субмаксимальної інтенсивності у жінок-боксерів високого класу, які є лідерами чи аутсайдерами у команді, досягається за рахунок різного співвідношення кількості нанесених ударів та їх сили. В аутсай-

\section{Література}

1. Аварханов МА. Деятельность боксеров, участвующих в соревнованиях с различной формулой ведения боя [Activities of boxers participating in competitions with different fighting formulas]. Проблемы и перспективы развития спортивного образования, науки и практики: материалы науч. конф. молодых ученых. Москва: МПГУ; 2017: 6-15.

2. Арансон МВ, Озолин ЭС, Шустин БН. Совершенствование специальной функциональной подготовленности спортсменов высокого класса в боксе и баскетболе [Improving the special functional readiness of highclass athletes in boxing and basketball]. Научно-методическое обеспечение физической культуры и спорта: [метод. рекомендации]. Москва; 2017: 42-64.

3. Гаськов АВ, Кузьмин ВА, Кудрявцев МД, Ермаков СС. Успешность развития общих и специальных физических качеств на различных стадиях подготовки боксеров-студентов [The success of the development of general and special physical qualities at various stages of training student boxers]. Физ. воспитание студентов. 2016:1:4-11.

4. Иорданская ФА. Мужчина и женщина в спорте высших достижений (проблемы полового диморфизма) [Man and woman in elite sports (problems of sexual dimorphism)]: монография. Москва: Советский спорт; 2012. $256 \mathrm{c}$.

5. Кийзбаев МС, Кенжебаев А, Аширов Д. Определение состояния физической и функциональной подготовленности боксеров высокой квалификации [Determination of the state of physical and functional дерів дещо більший «тоннаж» ударів за тест «40 с» досягається за рахунок більшої сили, що розвивається під час нанесення удару, при меншій їх кількості. У лідерів, навпаки, дещо менший «тоннаж» ударів досягається за рахунок більшої їх кількості при меншій силі їх нанесення.

3. Існує високий рівень зв'язку спеціальної працездатності (сила удару, кількість нанесених ударів, час нанесення удару, сумарний «тоннаж» ударів, градієнт ефективності ударів) жінок-боксерів високого класу з показниками реакції кардіореспіраторної системи. Для забезпечення високого темпу нанесення ударів, навіть за умови короткочасної роботи анаеробного характеру, найбільш сприятливим $€$ економний тип дихальної реакції, коли високий рівень легеневої вентиляції фрормується за рахунок збільшення дихального об'єму, як при виконанні навантаження, так і в подальшому відновлювальному періоді.

4. Більш високий ступінь позитивного взаємозв'язку кількості нанесених ударів з рівнем виділення $\mathrm{CO}_{2}(r=0,530 ; p<0,05)$, ніж $з$ рівнем споживання $\mathrm{O}_{2}(r=0,263 ; p>0,05)$ свідчить про більше значення дихальної компенсації наростаючого ступеня ацидозу при навантаженнях максимальної інтенсивності для досягнення високого рівня спеціальної працездатності спортсменок.

Перспективи подальших досліджень. Визначити особливості змагальної діяльності та спортивної підготовки жінок-боксерів високого класу на сучасному етапі розвитку жіночого боксу.

readiness of highly qualified boxers]. Вестн. физ. культуры и спорта 2016;3(15):45-57.

6. Киселев ВА. Совершенствование спортивной подготовки высококвалифицированных боксеров [Improvement of sports training of highly qualified boxers]: учебное пособие. Москва: Физическая культура; 2006. 127 с.

7. Киселев ВА, Черемисинов ВН. Направленность тренировочных средств боксера [The focus of a boxer's training aids]. В: Актуальные проблемы биохимии и биоэнергетики спорта XXI века: материалы Всероссийской науч.-практ. интернет-конф. с междунар. участием; 2017 Апр. 10-26. Москва; 2017: 89-97.

8. Киприч СВ, Беринчик ДЮ. Специфические характеристики функционального обеспечения специальной выносливости боксеров [Specific characteristics of the functional provision of special endurance for boxers]. Педагогика, психология и мед.-биол. проблемы физ. воспитания и спорта. 2015; 3: 20-27

9. Климовицкий ВГ, Колодежный АВ, Вертыло НА. Применение математической статистики в медико-биологических исследованиях [Application of mathematical statistics in biomedical research]: монография. Донецк: Донеччина; 2004. 216 с.

10. Кличко В, Савчин М. Система тестов для оценки специальной подготовленности боксеров высокой квалификации [The system of tests for assessing the special preparedness of highly qualified boxers]. Наука в олимп. спорте. 2000; 2:23-30. 
11. Лисицын ВВ. Специфика технико-тактической подготовки женщин-боксеров высокого класса [Specificity of technical and tactical training of high-class female boxers]. Москва: ЛЕНАНД; 2014. 352 c.

12. Лысенко ЕН. Особенности структуры функциональной подготовленности высококвалифицированных баскетболистов различной специализации [Features of the structure of functional readiness of highly qualified basketball players of various specializations]. Наука в олимп. спорте. 2010;12:80-86.

13. Лысенко Е, Станкевич Л, Гатилова Г. Физическая работоспособность и особенности мобилизации энергетических механизмов при нагрузках различного характера у квалифицированных спортсменов различной специализации [Physical performance and features of mobilization of energy mechanisms during loads of various nature in qualified athletes of various specializations]. Наука в олимп. спорте. 2013;1:61-65.

14. Лысенко ЕН, Беринчик ДЮ. Функциональное обеспечение специальной работоспособности у квалиффицированных боксеров при выполнении специализированных тестов анаэробного характера [Functional provision of special performance in qualified boxers when performing specialized tests of anaerobic nature]. Вісн. Черкас. ун-ту. Серія Біологічні науки. Черкаси; 2018;1:80-91.

15. Михайлюк ВВ та ін. Деякі психологічні особливості дівчат-боксерів різної кваліфікації [Some psychological features of girls boxers of different qualifications]. Слобожан. наук.-теорет. вісн. 2011;1:152-155.

16. Мищенко ВС, Павлик АИ, Савчин С, Дьяченко АЮ, Лысенко ЕН и др. Функциональная подготовленность квалифицированных спортсменов: подходы к повышению специализированности оценки и направленному совершенствованию [Functional readiness of qualified athletes: approaches to increasing the specialization of assessment and directed improvement]. $\mathrm{Ha}$ ука в олимп. спорте. Спец. выпуск. 1999: 61-69.

17. Панков ГА. Современные представления о механизмах влияния скоростно-силовых физических нагрузок на организм женщины [Modern ideas about the mechanisms of the influence of speed and force physical exertion on a woman's body]. Адаптив. физ. культура. 2010;2(42):17-20.

18. Савчин МП. Динамика специальной работоспособности боксера сборной команды Украины в прошедшем Олимпийском цикле [Dynamics of special working capacity of a boxer of the national team of Ukraine in the last Olympic cycle]. Наука в олимп. спорте. 2013;2:55-63.

19. Савчин М, Сколоздра Я, Михайлик Б та ін. Комп'ютеризація хронодинамометричних вимірів в ударних одноборствах [Computerization of chronodynamometric measurements in martial arts]. Молода спорт. наука України. 2008;1:307-314.

20. Сактаганова СС, Ибраимов ЕС, Родыгина ЮК. Комплексный анализ психических состояний у высококвалифицированных женщин-боксеров в предстартовый период [Comprehensive analysis of mental states in highly qualified female boxers in the pre-start period]. Ученые зап. ун-та им. П. Ф. Лесгафта. 2016; 12(142):193-198.

21. McKean MR, Stockwell TB, Burkett BJ. Response to Constant and Interval Exercise Protocols in the Elderly . Journal of Exercise Physiology online. 2012; 15 (2):30-39.

markizalus14@gmail.com

saidabox@ukr.net

shi-oksana@ukr.net

lanasvet778899@gmail.com

olena_kolos@ukr.net

Надійшла 28.07.2021 